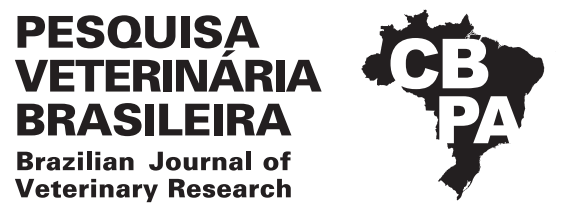

Pesq. Vet. Bras. 39(8):587-591, August 2019 DOI: 10.1590/1678-5150-PVB-6011

Original Article

ISSN 0100-736X (Print)

ISSN 1678-5150 (Online)

\title{
Enterotoxin-encoding genes in Staphylococcus aureus from buffalo milk ${ }^{1}$
}

\author{
Emmanuella O. Moura², Adriano H.N. Rangel², Cláudia S. Macêdo², \\ Stela A. Urbano ${ }^{2}$, Luciano P. Novaes ${ }^{2}$ and Dorgival M. Lima Júnior ${ }^{3 *}$ (D)
}

\begin{abstract}
Moura E.O., Rangel A.H.N., Macêdo C.S., Urbano S.A., Novaes L.P. \& Lima Júnior D.M. 2019. Enterotoxin-encoding genes in Staphylococcus aureus from buffalo milk. Pesquisa Veterinária Brasileira 39(8):587-591. Universidade Federal de Alagoas, Campus Arapiraca, Av. Manoel Severino Barbosa s/n, Bom Sucesso, Arapiraca, AL 57309-005, Brazil. E-mail: juniorzootec@yahoo.com.br

This paper investigated the occurrence of Staphylococcus aureus and the detection of enterotoxin-encoding genes of these strains in milk collected from 30 Murrah buffaloes used to produce dairy products in Brazil. A total of 68 strains of Staphylococcus aureus were found as identified by conventional laboratory tests, and thus screened for sea, seb, sec, sed, see, seg, seh and sei enterotoxin-encoding genes by polymerase chain reaction (PCR). Twelve strains containing enterotoxin-amplified genes were found, with higher expression for the sei and seh genes. These results can be attributed to animal health and inadequate cleaning of the equipment, indicating the need for better quality control in animal production and health lines. The results of this study with the presence of pathogens and their enterotoxigenic potential indicate a source of food poisoning, as well as being a pioneering study in the detection of new enterotoxins for buffalo milk.
\end{abstract}

INDEX TERMS: Enterotoxin, encoding genes, Staphylococcus aureus, buffalo, animal origin food, food microbiology, mastitis, milk quality, bovine.

\begin{abstract}
RESUMO.- [Genes codificadores de enterotoxinas em Staphylococcus aureus no leite de búfalas.] Este estudo investigou a ocorrência de isolados de Staphylococcus aureus e a detecção de genes que codificam a enterotoxigenicidade dessas cepas em leite de búfala utilizado na produção de laticínios no Brasil. As amostras foram coletados em 30 búfalos da raça Murrah, identificado por testes laboratoriais convencionais, foram identificados um total de 68 cepas de $S$. aureus e rastreados para os genes que codificam a enterotoxina sea, seb, sec, sed, see, seg, seh and sei por reação em cadeia da polimerase (PCR). Doze cepas contendo genes da enterotoxina foram amplificadas, com maior expressão para os genes sei e seh. Esses resultados podem ser atribuídos à saúde animal e à higiene inadequada do equipamento, indicando

\footnotetext{
${ }^{1}$ Received on November 19, 2018.

Accepeted for publication on March 31, 2019.

${ }^{2}$ Graduate Studies Program in Animal Production, Unidade Acadêmica Especializada em Ciências Agrárias, Universidade Federal do Rio Grande do Norte (UFRN), RN-160 Km 3, Cx. Postal 07, Distrito de Jundiaí, Macaíba, RN 59280-000, Brazil.

${ }^{3}$ Universidade Federal de Alagoas (UFAL), Campus Arapiraca, Av. Manoel Severino Barbosa s/n, Bom Sucesso, Arapiraca, AL 57309-005, Brazil. *Corresponding author: juniorzootec@yahoo.com.br
}

a necessidade de melhor controle de qualidade nas linhas de produção e saúde animal. Os resultados desta pesquisa, com a presença de patógenos e seu potencial enterotoxigênico, indicam uma fonte de intoxicação alimentar, além de ser uma pesquisa pioneira na detecção de novas enterotoxinas para o leite de búfala.

TERMOS DE IDEXAÇ̃̃O: Genes codificadores, enterotoxinas, Staphylococcus aureus, búfalos, produtos de origem animal, microbiologia de alimentos, mastite, qualidade de leite, leite de búfala, bovinos.

\section{INTRODUCTION}

Staphylococcus aureus is among the most prevalent etiological agents of subclinical mastitis in different animal species, and it stands out for having high pathogenic potential and virulence. The $S$. aureus microorganism is equipped with pathogenic mechanisms that damage the host's tissue and facilitate colonization; moreover, $S$. aureus is one of the major causative agents of foodborne diseases worldwide and contributes to high food poisoning incidence (Silva et al. 2013). As it is frequently isolated in raw milk, it is considered responsible for an increase in milk somatic cell count 
(SCC), and consequent reduction in productivity while also compromising the milk's nutritional composition (Silva et al. 2000). The enterotoxins produced by $S$. aureus (known as staphylococcal enterotoxins - SEs) are heat-resistant, which preserves their biological activity after milk pasteurization or ultra-high-temperature processing. This fact explains disease outbreaks where milk and milk products have been directly implicated via SEs (Rosa et al. 2015).

Therefore, the objective of this study was to investigate the occurrence of Staphylococcus aureus in raw buffalo milk and also assess the presence of staphylococcal enterotoxin-encoding genes.

\section{MATERIALS AND METHODS}

Ethics statement. The project for this study was submitted to the Ethics Committee in Animal Use (CEUA), receiving opinion number $007 / 2015$, being free and approved for implementation from the legal point of view, according to Law No. 11,794, 2008.

Sample collection and Staphylococcus identification. Raw milk samples for Staphylococcus spp. isolation which had been collected from 30 Murrah buffaloes in a commercial herd operation located in Taipu (Rio Grande do Norte - RN, Brazil) were put into a refrigerator at $4^{\circ} \mathrm{C}$ for 8 hours. Group 1 consisted of 15 randomly selected animals in early lactation stage with production $\geq 15 \mathrm{~kg}$ milk/day, and Group 2 consisted of 15 animals in late lactation stage with production $\leq 8 \mathrm{~kg}$ milk/day. Buffalo cows were kept in pasture with access to concentrate supplementation according to their productivity, and were milked twice daily at 5:00 a.m. and 3:00 p.m. by a mechanized system (milking parlor). Milk was collected from all mammary quarters directly from the animals' teats. The samples were collected in sterile bottles $(20 \mathrm{~mL})$ after application of hygienic procedures consisting of the first jets of milk, asepsis of the ceilings by a chlorinated solution, drying of the ceilings with a disposable towel, followed by disinfection of the posterior end of the ceiling and sphincter with cotton soaked in $70 \%$ alcohol (v/v), with the handler using disposable gloves at all times.The samples were then transported under refrigeration to the Quality Control Laboratory and the Microbiology Laboratory of Food Engineering at the "Universidade Federal do Rio Grande do Norte", Natal/RN, Brazil.

For Staphylococcus aureus isolation, $25 \mathrm{~mL}$ of milk was taken from each sample and diluted in $225 \mathrm{~mL}$ of sterile peptone water $\left(0.1 \%\right.$ wt./vol.). Decimal serial dilutions $\left(10^{-1}\right.$ and $\left.10^{-2}\right)$ of each sample were then made from this stock solution, and 1-mL aliquots were plated in duplicate into Baird-Parker agar enriched with egg yolk emulsion and $50 \%$ potassium tellurite at $1.0 \%$ and were then incubated at $36^{\circ} \mathrm{C}$ for $48 \mathrm{~h}$ for colony growth (Silva et al. 2001). Next, 5 typical and 5 atypical colonies were randomly selected and inoculated into brain heart infusion broth at $36^{\circ} \mathrm{C}$ for $24 \mathrm{~h}$. Isolated colonies were used for additional identification tests such as Gram staining (Koneman et al. 2001), as well as assays for catalase and coagulase production (Silva et al. 2001). Tests for acetoin production (Voges Proskauer test), 0.04IU bacitracin resistance, and the fermentation of mannitol, maltose, and trehalose sugars were performed according to Koneman et al. (2001). In addition, an acriflavine resistance test was performed according to Brito et al. (2002).

Antimicrobial susceptibility testing. An antibiotic sensitivity test was also performed by the VidaVet laboratory through the disk diffusion method in agar for the identified samples, according to the methodology recommended by the National Committee for Clinical Laboratory Standards (NCCLS 2003), using the bases of commercial products available for clinical treatments of samples from cows with mastitis and different antimicrobials of samples from each buffalo. For this, 17 active ingredients were used in these sensitivity tests, as these drugs are the most used by breeders and all commercial antibiotics that the veterinarian can choose as the one which best applies to the inflammatory situation of each animal. The antibiotics applied for the antibiogram were: PMN = Novobiocin $(40 \mu \mathrm{g})+$ Penicillin G procaine $(40 \mu \mathrm{g}), \mathrm{CEQ}=$ Cefquinome $(30 \mu \mathrm{g}), \mathrm{AMO}=$ Amoxicillin $(10 \mu \mathrm{g})$, DUL = Danofloxacin $(5 \mu \mathrm{g}), \mathrm{CTF}=$ Ceftiofur $(30 \mu \mathrm{g}), \mathrm{CL}=$ Cephalexin $(30 \mu \mathrm{g}), \mathrm{CN}=$ Gentamicin $(10 \mu \mathrm{g}), \mathrm{TE}=$ Tetracycline $(30 \mu \mathrm{g})$, $\mathrm{AM}=$ Ampicillin $(10 \mu \mathrm{g}), \mathrm{ENO}=$ Enrofloxacin $(5 \mu \mathrm{g}), \mathrm{NEO}=$ Neomycin $(30 \mu \mathrm{g})$, SUT Sulfatrim $(25 \mu \mathrm{g}), \mathrm{AMC}=$ Ampicillin + Colistin $(30 \mu \mathrm{g})$, $\mathrm{CNM}=$ Cefalonium $(30 \mu \mathrm{g}), \mathrm{ACA}=$ Amoxicillin $(20 \mu \mathrm{g})+$ clavulanic acid $(10 \mu \mathrm{g}), \mathrm{OXA}=$ Oxacillin $(1 \mu \mathrm{g})$, and CIP $=$ Ciprofloxacin $(5 \mu \mathrm{g})$.

Detection of enterotoxin-encoding genes. Genomic DNA of isolates was extracted by thermal lysis according to the protocol recommended by Pacheco et al. (1997). After extraction, the DNA was kept at $-20^{\circ} \mathrm{C}$ and quantified in a spectrophotometer (Nanodrop 2000 Termo Cientific ${ }^{\circledR}$, Wilmington/DE). Polymerase chain reactions for the detection of sea, seb, sec, sed, see, seg, seh, and sei genes (Johnson et al. 1991, Mehrotra et al. 2000, Jarraud et al. 2002) consisted of a mixture of $1 \mu \mathrm{L}$ of primer (Invitrogen, Carlsbad, California) (Table 1), $12.5 \mu \mathrm{L}$ of $1 \mathrm{X}$ Master Mix ( $\mathrm{dNTP} \mathrm{MgCl}_{2}$, and Taq DNA polymerase; Promega, Madison/WI), $5.5 \mu \mathrm{L}$ of nuclease-free water (Promega), and $5 \mu \mathrm{L}$ of total DNA for a final volume of $25 \mu \mathrm{L}$. Amplification for all genes was performed in a thermocycler (BIO-RAD, Hercules/CA) with the following cycles: initial denaturation for 5 minutes at $94^{\circ} \mathrm{C}$ and then 30 cycles at $94^{\circ} \mathrm{C}$ for 2 minutes (denaturation) and $72^{\circ} \mathrm{C}$ for 1 minute (extension). The various temperatures used in the annealing step are shown in Figure 1. Final extension was performed at $72^{\circ} \mathrm{C}$ for 5 minutes (Rall et al. 2010).

The PCR-amplified samples were analyzed by electrophoresis for 50 minutes at $110 \mathrm{~V}$ through a $1.5 \%$ agarose gel (Invitrogen, USA) in 0.5X TBE (0.09 M Tris-HCl, 0.09M boric acid, 2mM EDTA,

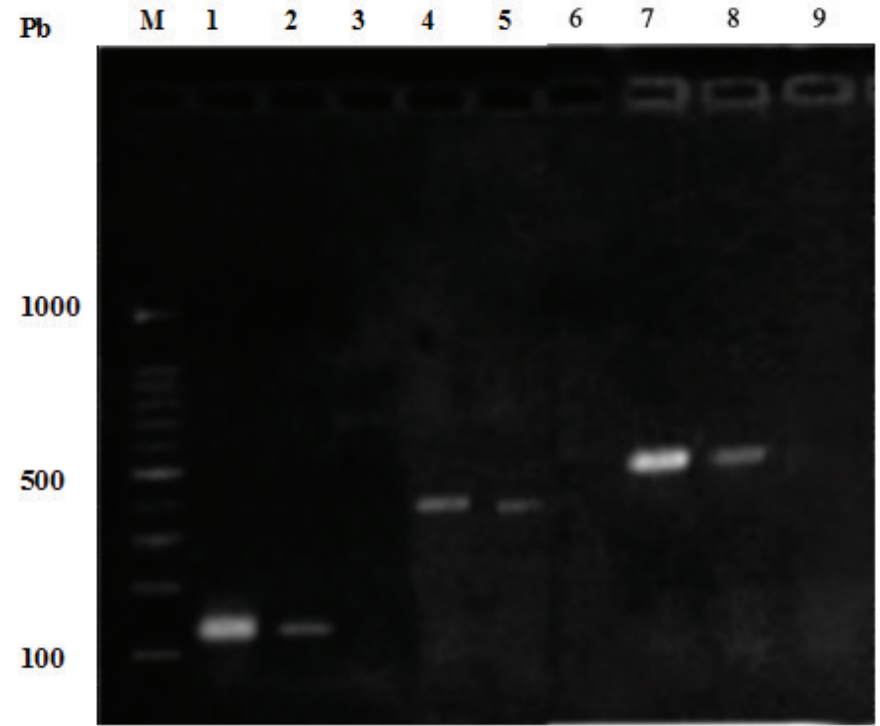

Fig.1. Agarose gel containing the amplified PCR products from enterotoxin-encoding genes of Staphylococcus aureus. M =1,000bp DNA ladder, 1 = positive control for sea $(120 \mathrm{bp}), 2=$ positive sample for sea (120 bp), 3 = negative control for sea, $4=$ positive control for seh (376 bp), 5 = positive samples for seh (376 bp), $6=$ negative control for $\mathrm{seh}, 7=$ positive control for sei $(577 \mathrm{bp})$, $8=$ positive samples for sei, and $9=$ negative control for sei. 
Table 1. Primers and temperature used for the detection of staphylococcal enterotoxin genes

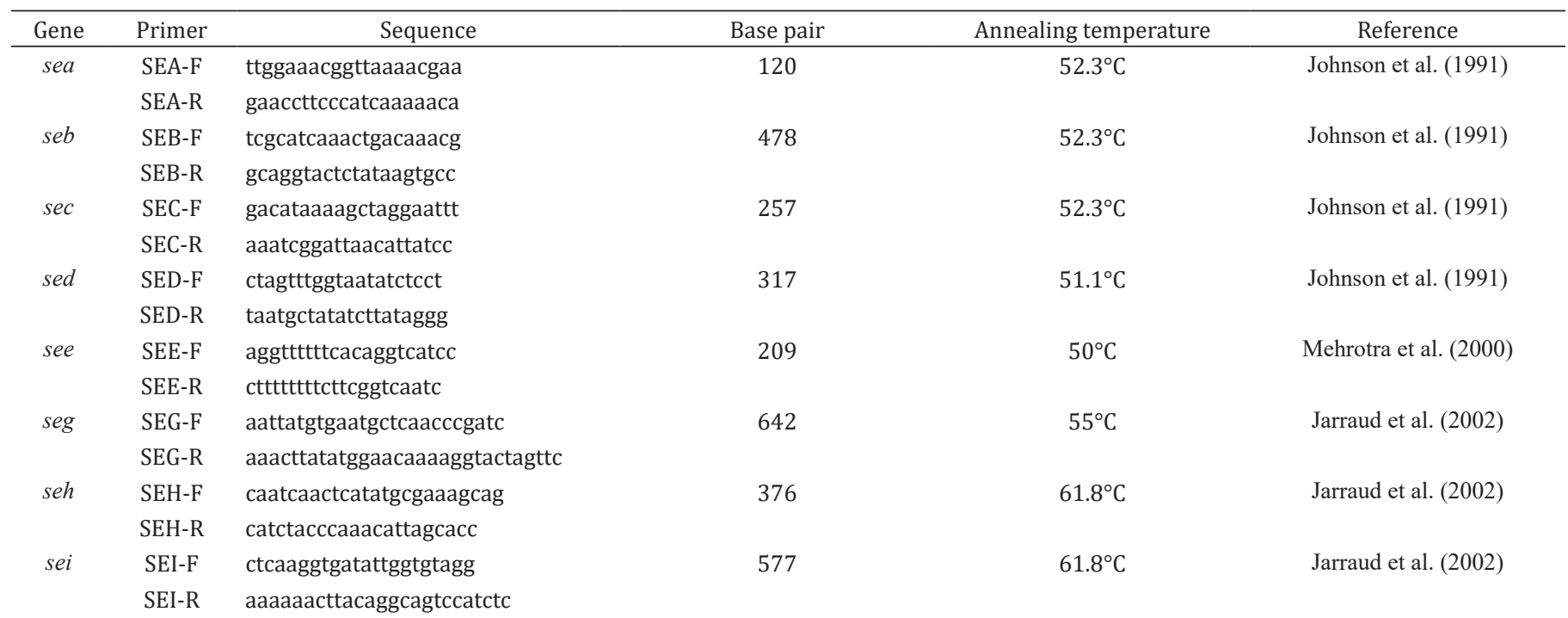

pH 8.3; Bio-Rad, USA). A 100 bp ladder (New England Biolabs, USA) was used for reference. The gel was stained in a solution of Gel Red 3X (Biotium, USA) for 30 minutes and visualized by a Gel Doc ${ }^{\mathrm{TM}}$ EZ System (Bio-Rad, USA). Positive controls used for comparison included Staphylococcus aureus FRI 996 (sea, seb, and sed), S. aureus ATCC 19095 (sec, seh, and sei), S. aureus ATCC 27664 (see), and S. aureus ATCC 23235 (seg).

Descriptive statistics were used (M S. Exel $\left.{ }^{\odot}\right)$.

\section{RESULTS}

\section{Staphylococcus identification}

One hundred fifty (150) isolates of Staphylococcus spp. were found in the 30 analyzed samples of buffalo milk. Using the coagulase test, 93 isolates (62\%) were identified as producers of the coagulase enzyme Staphylococcus (CPS), and of these, 38 (40.9\%) were isolated from the milk samples from Group 1 and 55 (59.1\%) from Group 2. Of the total CPS, $68(73.1 \%)$ were identified as S. aureus. In addition, 57 (38\%) isolates were identified as coagulase-negative Staphylococcus.

\section{Antimicrobial susceptibility testing}

The antibiogram results indicated that $13(76.47 \%)$ of the 17 antibiotics tested were sensitive to all isolates with $100 \%$ efficiency, being: cefquinome, danofloxacin, tetracycline, ampicillin, enrofloxacin, ceftiofur, sulfatrim, amoxicillin + clavulanic acid, cefalonium, ciprofloxacin, oxacillin, amoxicillin, novobiocin + penicillin $\mathrm{G}$ procaine. The other tested antibiotics (cephalexin, gentamicin, neomicin and ampicilin + colistin) showed $22.22 \%$ resistance for the first three and $11.11 \%$ for the last one.

\section{Detection of enterotoxin-encoding genes}

Thirty randomly selected Staphylococcus aureus isolates were submitted to encoding gene detection for classic staphylococcal toxins (sea, seb, sec, sed and see) and new enterotoxins (seg, seh and sei). Of these 30 isolates, enterotoxigenic genes were found in 12 isolates (40\%), including $8(66.7 \%)$ from animals in Group 1, and 4 (33.3\%) from animals in Group 2. Genes involved in sea synthesis were amplified in 1 sample
Table 2. Enterotoxin-encoding genes found in buffaloes belonging to Group 1 (early lactation animals) and Group 2 (late lactation animals)

\begin{tabular}{clcc}
\hline Enterotoxins $^{\mathrm{a}}$ & $\mathrm{n}(\%)$ & Group 1 & Group 2 \\
\hline $\mathrm{A}$ & $1(8.3)$ & 0 & 1 \\
$\mathrm{H}$ & $5(41.7)$ & 0 & 5 \\
$\mathrm{I}$ & $9(75)$ & 3 & 6 \\
Total & 12 & 6 & 6
\end{tabular}

$\bar{a}$ The presence of genes in association were observed in 3 samples among the enterotoxins found, specifically $\mathrm{A}+\mathrm{I}$ in 1 sample, and $\mathrm{H}+\mathrm{I}$ in 2 samples.

(3.33\%, Group 2), the seh gene was amplified in 5 samples (16.6\%, Group 1), and the sei gene was amplified in 9 samples (30.0\%), being 2 from Group 1 and 7 from Group 2. Moreover, 3 samples $(25 \%)$ were amplified for 2 genes in association ( 1 sample for sea plus sei and 2 samples for seh plus sei) as shown in Table 2 and Figure 1. Regarding the other seb, sec, sed, see and seg genes, 18 (60\%) were not amplified for any isolates in this study.

\section{DISCUSSION}

A lack of strict hygienization of equipment and animal health for food production of animal origin is considered as the main source of food contamination, since these deficiencies can lead to the cultivation of enterotoxin-producing bacteria. Staphylococcus aureus isolated from raw buffalo milk presented most of the sei and seh genes for staphylococcal enterotoxins; this is important because these genes are capable of causing food poisoning outbreaks and only a few of these genes have been studied for this species.

Antibiotic resistance found in this study was also the same as those found by all opportunists as etiologic agents of mastitis, and similar to the results found by Barros et al. (2013). The antibiotic widely used in the treatment of mastitis is tetracycline, which showed $100 \%$ efficiency in this study, where all isolated samples of Staphylococcus spp. were sensitive to the same active principle. Gentamicin and neomycin, which 
has shown high efficacy in vitro against mastitis agents in different studies, can be ineffective, especially when its use is frequent and inappropriate (Brito et al. 2001), and which may have occurred in animals of the present study which showed resistance to these active principles. Antimicrobial therapy is one of the main tools for controlling mastitis in herds, enabling treatment to be performed with greater efficiency and safety, but it is important to emphasize the importance of assessing antimicrobial susceptibility in vitro for each case prior to indication of treatment, since each property has a different reality and differences in milking hygiene.

Studies of enterotoxin-encoding gene expression in Staphylococcus aureus strains obtained from raw milk samples of different animal species have demonstrated a large variability among isolates. Such variation included differences in the presence or absence of genes and the diversity of the identified types, as well as differences in the number of strains producing staphylococcal enterotoxins and the types of enterotoxins produced (Paulin et al. 2012). For the $S$. aureus strains isolated in the present study, the sei gene was the most commonly found, followed by the seh gene and sea. A low occurrence (3.33\%) of classic enterotoxigenic $S$. aureus isolates was observed in this study, with the sea gene being the only classic staphylococcal enterotoxin gene detected. Silva et al. (2013) found that the genes involved in the synthesis of seb, sec, sed and see were not amplified in any of the isolates of mastitic milk from dairy cows in Brazil.

Oliveira et al. (2011) and Rahimi \& Alian (2013) reported the presence of the sea and sea and sed classic staphylococcal enterotoxin genes, respectively, when characterizing Staphylococcus spp. isolated from buffalo milk, which is corroborated by the current results. A pioneering study of toxigenic $S$. aureus in milk from buffaloes with mastitis was described by Bonna et al. (2004), who showed that only enterotoxin A was detected among the classic staphylococcal enterotoxins, and which were observed in $51.6 \%$ of the studied herds.

Similar to the present study, Luz (2009) also did not find the presence of the $s e b, s e c$, sed and see genes; however, at least 1 of the enterotoxin-encoding $\mathrm{H}$ and I genes was detected in $93.6 \%$ of the Staphylococcus aureus strains, and the presence of seh plus sei $(1.1 \%)$ genotype association was found among the isolates which were positive for the toxigenic seg, seh, sei, and sej genes. The absence of genes for classic toxins and the presence of genes for other toxins may be associated with the duration and geographical distribution of the toxigenic isolates. In fact, according to Luz (2009), the gene profiles for staphylococcal enterotoxins seem to be variable among different years and geographical origins.

The occurrence of staphylococcal enterotoxins found in $40 \%$ of the isolated Staphylococcus aureus in the present study is high compared to Ferreira et al. (2014), who reported an occurrence rate of $19.5 \%$. Therefore, our results indicate that the presence of $S$. aureus which have enterotoxinogenic potential in raw buffalo milk may be a source of food poisoning.

\section{CONCLUSIONS}

Several studies have investigated enterotoxins in cattle and goats, but there are few such studies on buffaloes. Additionally there is a lack of information on the occurrence of staphylococcal non-classical enterotoxin-encoding genes from milk. We highlight the need for further research and greater attention to this species to estimate its impact on buffalo milk.

Although this study does not assess the expression of enterotoxin-encoding genes, its detection is directly indicated by the enterotoxigenic potential of these strains, highlighting the need for better quality control in animal production and health lines, as well as future studies to ensure the health of the population, as buffalo milk is exclusively intended for manufacturing dairy products and such transmissions of enterotoxins will also be present in the products.

Acknowledgements.- The authors would like to acknowledge the financial support received from "Fundação de apoio à Pesquisa do Estado Rio Grande do Norte” (FAPERN)/“Conselho Nacional de Desenvolvimento Científico e Tecnológico" (CNPq) and Dr. Haíssa Roberta Cardarelli of the "Universidade Federal da Paraíba" (UFPB) for collaborating on the review and correction of this work.

Conflict of interest statement.- The authors declare that they have no conflicts of interest.

\section{REFERENCES}

Barros J.P.N., Lopes L.V., Lima D.M., Oliveira A. \& Botteon R.C.C.M. 2013. Limitações ao uso do antibiograma no tratamento e controle das mastites na rotina das propriedades leiteiras. Revta Bras. Med. Vet. 35(3):212-216.

Bonna I.C.F., Ferreira G.S., Carmo L.S. \& Vieira-da-Mota O. 2004. Estudo da microbiota da glândula mamária de búfalas, com ênfase para Staphylococcus aureus produtores de toxinas. Revta Ciênc. Vida, UFRRJ 24(1):485-486.

Brito M.A.V.P., Brito J.R.F., Silva M.A.S. \& Carmo R.A. 2001. Concentração mínima inibitória de dez antimicrobianos para amostras de Staphylococcus aureus isoladas de infecção intramamária bovina. Arq. Bras. Med. Vet. Zootec. 53(Suppl.5):531-537. <http://dx.doi.org/10.1590/S0102$09352001000500003>$

Brito M.A.V.P., Campos G.M.D.M. \& Brito J.R.F. 2002. Esquema simplificado para identificação de estafilococos coagulase-positivos isolados de mastite bovina. Ciência Rural 32(1):79-82. <http://dx.doi.org/10.1590/S0103$84782002000100014>$

Ferreira D.H., Carvalho M.D.G.X., Nardelli M.J., Sousa F.G.C. \& Oliveira C.J.B. 2014. Occurrence of enterotoxin-encoding genes in Staphylococcus aureus causing mastitis in lactating goats. Pesq. Vet. Bras. 34(7):633-636. <http:// dx.doi.org/10.1590/S0100-736X2014000700004>

Jarraud S., Mougel C., Thioulouse J., Lina G., Meugnier H., Forey F., Nesme X., Etienne J. \& Vandenesch L. 2002. Relationships between Staphylococcus aureus genetic background, virulence factors, agr groups (alleles), and human disease. Infect. Immunity J. 70(2):631-641. < http://dx.doi.org/10.1128/ IAI.70.2.631-641.2002><PMid:11796592>

Johnson W.M., Tyler S.D., Ewan E.P., Ashton F.E., Pollard D.R. \& Rozee K.R. 1991. Detection of genes for enterotoxins, exfoliative toxins, and toxic shock syndrome toxin 1 in Staphylococcus aureus by the polymerase chain reaction. J. Clin. Microbiol. 29(3):426-430. <PMid:2037659>

Koneman E.W., Allen S.D., Janda W.M., Schreckenberger P.C. \& Winn Junior W.C. 2001. Diagnóstico Microbiológico: texto e atlas colorido. 5th ed. Editora Médica e Científica, Rio de Janeiro. 1465p.

Luz I.S. 2009. Molecular characterization of toxins in Staphylococcus aureus isolated from milk and 'coalho' cheese in cities from the Agreste region of Pernambuco. Revta Inst. Med. Trop. 51(3):177. <http://dx.doi.org/10.1590/ S0036-46652009000300010>

Mehrotra M., Wang G. \& Johnson W.M. 2000. Multiplex PCR for detection of genes for Staphylococcus aureus enterotoxins, exfoliative toxins, toxic shock syndrome toxin 1, and methicillin resistance. J. Clin. Microbiol. 38(3):1032-1035. <PMid:10698991> 
NCCLS 2003. Performance Standards for Antimicrobial Disk Susceptibility Tests. National Committee for Clinical Laboratory Standards, Wayne. 31p.

Oliveira A.A.F., Pinheiro Junior J.J.W., Mota R.A., Cunha M.L.R.S., Lopes C.A.M. \& Rocha N.S. 2011. Phenotype characterization of Staphylococcus species strains isolated from buffalo (Bubalus bubalis) milk. J. Vet. Diagn. Invest. 23(6):1208-1211. <http://dx.doi.org/10.1177/1040638711428946> $<$ PMid:22362803>

Pacheco A.B., Guth B.E., Soares K.C., Nishimura L., Almeida D.F. \& Ferreira L.C. 1997. Random amplification of polymorphic DNA reveals serotype-specific clonal clusters among enterotoxigenic Escherichia coli strains isolated from humans. J. Clin. Microbio. 35(6):1521-1525. <PMid:9163473>

Paulin S., Horn B. \& Hudson J.A. 2012. Factors influencing staphylococcal enterotoxin production in dairy products. Paper No.2012/07, MPI Technical, Ministry for Primary Industries, New Zealand Government. 78p.

Rahimi E. \& Alian F. 2013. Presence of enterotoxigenic Staphylococcus aureus in cow, camel, sheep, goat, and buffalo bulk tank milk. Veterinarski Arch. 83:23-30.

Rall V.L.M., Sforcin J.M., Augustini V.C.M., Watanabe M.T., Fernandes Junior A., Rall R., Silva M.G. \& Araújo Junior J.P. 2010. Detection of enterotoxin gens of Staphylococcus sp. Isolated from nasal cavities and hands of food handlers. Braz. J. Microbiol. 41(1):59-65. <http://dx.doi.org/10.1590/ S1517-83822010000100011> <PMid:24031464>

Rosa D.L.S.O., Acúrcio L.B., Sant'Anna F.M., Castro R.D., Rosa B.O., Sandes S.H.C., Silva A.M., Souza M.R. \& Cerqueira M.M.O.P. 2015. Detecção de genes toxigênicos, susceptibilidade antimicrobiana e antagonismo in vitro de Staphylococcus spp. isolados de queijos artesanais. Vigil. Sanit. Debate, Fundação Oswaldo Cruz 3:37-42.

Silva N., Junqueira V.C.A., Silveira N.F.A., Taniwaki M.H., Santos R.F.S. \& Gomes R.A.R. 2001. Manual de Métodos de Análise Microbiológica de Alimentos e Água. Editora Varela, São Paulo. 317p.

Silva N.C., Guimaraes F.F., Manzi M.P., Budri P.E., Gomez-Sanz E., Benito D., Langoni H., Rall V.L. \& Torres C. 2013. Molecular characterization and clonal diversity of methicillin-susceptible Staphylococcus aureus in milk of cows with mastitis in Brazil. J. Dairy Sci. 96(11):6856-6862. <http:// dx.doi.org/10.3168/jds.2013-6719><PMid:24054305>

Silva W.P.D., Destro M.T., Landgraf M. \& Franco B.D.G.M. 2000. Biochemical characteristics of typical and atypical Staphylococcus aureus in mastitic milk and environmental samples of Brazilian dairy farms. Braz. J. Microbiol. 31(2):103-106. <http://dx.doi.org/10.1590/S1517-83822000000200008> 